\title{
Faktor-faktor yang Mempengaruhi Perilaku Pemeliharaan Kebersihan gigi dan Mulut lbu Hamil di Puskesmas Kabupaten Kupang
}

\author{
Applonia, ${ }^{*}$ Bambang Priyono, ${ }^{* *}$ dan Niken Widyanti** \\ * Politeknik Kesehatan Kemenkes Kupang, Kota Kupang \\ **Bagian IImu Kesehatan Masyarakat, Fakultas Kedokteran Gigi, Universitas Gadjah Mada \\ *Jalan El Tari II-Kupang, Indonesia; e-mai; applonialeuobi@ymail.coml
}

\begin{abstract}
ABSTRAK
Pada masa kehamilan, rongga mulut mudah mengalami peradangan karena adanya perubahan hormonal yang menyebabkan gingiva menjadi sensitif bila kesehatan mulut tidak terjaga. Penelitian ini bertujuan untuk mengetahui faktor - faktor yang mempengaruhi perilaku pemeliharaan kebersihan gigi dan mulut ibu hamil di Puskesmas Kabupaten Kupang. Penelitian observasional analitik dengan rancangan cross sectional dilakukan dengan mengambil subyek penelitian 97 ibu hamil. Variabel bebas terdiri dari pengetahuan, sikap, dan kebiasaan menginang sedangkan variabel terikat terdiri dari perilaku pemeliharaan kebersihan gigi dan mulut ibu hamil. Alat ukur penelitian ini menggunakan kuesioner yang disusun dengan metode Likert untuk mengukur variabel sikap dan perilaku pemeliharaan kebersihan gigi dan mulut ibu hamil. Kuesioner dengan dua pilihan (benar atau tidak benar) untuk mengukur variabel pengetahuan serta kuesioner pilihan ganda untuk mengukur variabel kebiasaan menginang. Kuesioner tersebut telah diuji validitas dan reliabilitas. Analisis data menggunakan uji korelasi product moment dan regresi berganda pada tingkat signifikan $\alpha<0,05$. Hasil analisis regresi berganda menunjukkan variabel pengetahuan, sikap, dan kebiasaan menginang, berkolerasi secara signifikan dengan perilaku pemeliharaan kebersihan gigi dan mulut $(F=21,890, p=0,000)$. Ketiga variabel tersebut secara bersama - sama memberikan kontribusi sebesar $41,6 \%$. Pengetahuan memberikan pengaruh paling besar terhadap perilaku pemeliharaan kebersihan gigi dan mulut. Semakin baik pengetahuan dan sikap terhadap pemeliharaan kebersihan gigi dan mulut, dan semakin kurang frekuensi menginang, semakin baik frekuensi kebersihan gigi dan mulut ibu hamil.

Maj Ked Gi. Juni 2014; 21(1): 20 - 26.
\end{abstract}

Kata kunci: perilaku, sikap, kebiasaan menginang, ibu hamil,

ABSTRACT: Factors Affecting Oral And Dental Hygiene Maintaining Behaviour Of The Pregnant Women In Public Health Centre Of Kupang Regency. During pregnancy, woman's oral cavity becomes inflamed easily due to hormonal changes so that gingiva becomes sensitive if the oral hygiene is not well maintained. The purpose of this study is to examine factors that influence the oral and dental hygiene maintaining behavior of pregnant women at Public Health Centre of Kupang Regency. An observational analytical study with cross sectional design was conducted on 97 pregnant women as the subject research. Independent variables were knowledge, attitude and betel chewing habit, and dependant variables were oral and dental hygiene maintaining behavior of pregnant women. Variables of attitude, oral and dental hygiene maintaining behavior of the pregnant women was assed using questionnaire with Likert Scale method. Questionnaire with two options (true and false) was used to measure knowledge variable, and multiple choice questionnaires were used to measure betel chewing habitvariable. Questionnaire was tested its validity and reliability. The data were analyzed using the multiple regression analysis at the significant rate $\alpha<0,05$. The result of multiple regression analysis showed that knowledge, attitude and betel chewing habit correlated very significantly on oral and dental hygiene maintaining behavior $(F=22.052, p=0.000)$, and those three variables gave collectively contributionof $41.6 \%$ on oral and dental hygiene maintaining behavior, while betel chewing habit correlated negatively on oral and dental hygiene maintaining behavior. Knowledge variable gave the greatest contribution on the oral and dental hygiene maintaining behavior. The better knowledge and attitude on oral and dental hygiene maintaining behavior and the less frequent betel chewing habit were, the better the oral and dental hygiene maintaining behavior will be.

Maj Ked Gi. Juni 2014; 21(1): 20 - 26.

Key words: behavior, betel chewing habit, pregnant women

\section{PENDAHULUAN}

Kehamilan merupakan suatu proses fisiologis yang menimbulkan perubahan pada tubuh wanita baik fisik maupun psikis. Pada masa kehamilan perlu dipersiapkan dengan baik, kesehatan ibu harus baik dan tidak mengalami kelainan sehingga pertumbuhan bayi dalam kandungan sehat. ${ }^{1}$ Selain pola makan yang seimbang juga diperlukan 
pemeriksaan kesehatan ibu secara menyeluruh termasuk pemeriksaan kesehatan gigi dan mulut karena wanita hamil rentan terhadap masalah kesehatan gigi dan mulut. ${ }^{2}$

Kebutuhan akan kesehatan gigi pada ibu hamil tidak didukung oleh kesadaran masyarakat terhadap kesehatan gigi. Berdasarkan Riskesdas ${ }^{3}$ $23,4 \%$ penduduk Indonesia menderita penyakit gigi dan mulut dengan prevalensi penyakit periodontal sebesar $70 \%$. Secara nasional menunjukkan bahwa masyarakat menggosok gigi setiap hari pada waktu mandi pagi atau sore sebesar $90,7 \%$, hanya $12,6 \%$ yang menggosok gigi sesudah makan pagi dan $28,7 \%$ sebelum tidur malam. Perilaku menggosok gigi terendah $74,7 \%$ di Propinsi Nusa Tenggara Timur. Hal ini mungkin disebabkan kurangnya pengetahuan dan kesadaran masyarakat terhadap kebersihan gigi dan mulut. Keadaan ini akan mempengaruhi kesehatan gigi wanita hamil di wilayah Kabupaten Kupang tersebut.

Pada wanita hamil, secara klinis terdapat perubahan pada gingiva. Beberapa studi menyatakan bahwa efek perubahan hormon akan mempengaruhi kesehatan gigi dan mulut wanita hamil, didapatkan $25-100 \%$ yang mengalami gingivitis, dan $10 \%$ mengalami granuloma pyogenik. ${ }^{4,5}$, Gingivitis kehamilan terlihat sejak trimester ke dua kehamilan dan mencapai puncaknya pada bulan ke delapan. Gingivitis kehamilan ini disebabkan oleh hormon wanita yaitu estrogen dan progesteron di dalam darah. Adanya perubahan hormonal yang disertai dengan vaskuler menyebabkan gingiva menjadi sensitif khususnya terhadap toksin maupun iritan lainnya, seperti plak dan kalkulus yang mengakibatkan gingiva meradang. ${ }^{4}$ Keadaan inflamasi ditandai dengan papilla interdental yang memerah, bengkak, mudah berdarah dan disertai rasa sakit sehingga mempengaruhi ibu hamil takut menggosok gigi dan dapat memperburuk keadaan rongga mulut. ${ }^{5}$ Pada masa kehamilan terjadi perubahan fisiologis yang sering disertai dengan perubahan sikap dan perilaku. Selain itu, perilaku kesehatan ibu hamil juga memiliki pengaruh yang sangat besar bagi dirinya sendiri dan janin. ${ }^{6}$
Berdasarkan data dari Profil Kesehatan Kabupaten/Kota se-Provinsi Nusa Tenggara Timur, cakupan kunjungan ibu hamil belum mencapai target nasional, ada 11 (sebelas) Kabupaten berada di bawah rata-rata $(62,7 \%)$. Kematian bayi dan ibu masih tinggi di Kabupaten Kupang Propinsi Nusa Tenggara Timur. $^{7}$ Puskesmas Baumata berada di perbatasan Kota, Kabupaten Kupang. Wilayah kerja meliputi 8 (delapan) desa yaitu: Bokong, Kuaklalo, Oeletsala, Oeltua, Baumata, Manefu,Tulun, dan RSS Baumata, dengan jangkauan pelayanan sangat luas dan transportasi yang sulit. Berdasarkan data kunjungan ibu hamil tahun 2011 sebesar 392, KI adalah pelayanan ibu hamil yang telah melakukan kunjungan pertama ke fasilitas pelayanan kesehatan untuk mendapatkan pelayanan antenatal sebesar 362 $(92,35 \%)$ sedangkan K4 adalah ibu hamil yang telah mendapatkan pelayanan paling sedikit empat kali kunjungan sebesar $325(82,91 \%){ }^{8}$

Salah satu kebiasaan masyarakat Nusa Tenggara Timur yang diturunkan dari generasi ke generasi adalah menginang. Budaya tersebut tidak dapat dihilangkan dalam kehidupan masyarakat. Kebiasaan menginang sudah lama dilakukan oleh wanita dan pria, baik tua maupun muda, hal ini juga menjadi sarana bersosialisai sehari - hari. ${ }^{9}$

Tujuan penelitian untuk mengetahui faktorfaktor yaitu pengetahuan, sikap dan kebiasaan menginang yang mempengaruhi perilaku pemeliharaan kebersihan gigi dan mulut ibu hamil di Puskesmas Kabupaten Kupang dan untuk mengetahui faktor yang paling dominan mempengaruhi perilaku pemeliharaan kebersihan gigi dan mulut pada ibu hamil di Puskesmas Kabupaten Kupang.

\section{METODE PENELITIAN}

Penelitian ini adalah analitik observasional dengan menggunakan rancangan cross sectional, ${ }^{11}$ dan telah mendapat persetujuan dari Komite Etik Fakultas Kedokteran Gigi UGM pada tahun 2013. Pengambilan sampel dengan teknik purposive sampling,,$^{11}$ berjumlah 97 ibu hamil yang berkunjung 
ke Poli KIA dan Posyandu di Puskesmas Baumata Kabupaten Kupang yang memenuhi kriteria inklusi: ibu hamil yang berada di wilayah kerja Puskesmas, usia 20 - 44 tahun, bisa membaca dan menulis, dan bersedia menjadi responden dengan mengisi informed consent.

Variabel bebas dalam penelitian ini terdiri dari pengetahuan, sikap, kebiasaan menginang, sedangkan variabel terikatnya antara lain perilaku pemeliharaan kebersihan gigi dan mulut ibu hamil. Pengambilan data dilakukan dengan menggunakan blangko isian untuk mengetahui karakteristik umur responden, umur kehamilan, kehamilan anak ke, serta kuesioner untuk mengukur pengetahuan tentang pemeliharaan kebersihan gigi dan mulut, sikap terhadap kesehatan gigi dan kebiasaan menginang, perilaku pemeliharaan kebersihan gigi dan mulut ibu hamil.

Pengetahuan pemeliharaan kebersihan gigi dan mulut diukur dengan memberikan nilai $\mathrm{i} 1$ untuk jawaban benar dan nilai 0 untuk jawaban salah, sehingga skor tertinggi adalah 9 dan skor terendah 0. Semakin tinggi jumlah nilai yang diperoleh semakin baik pengetahuan tentang pemeliharaan kebersihan gigi. Alat ukur sikap terhadap kesehatan gigi, kuesioner dibuat dengan menggunakan skala Likert. Nilai yang diperoleh dibuat kategori berdasarkan Penilaian Acuan Patokan (PAP) dengan menggunakan nilai tertinggi dan terendah. Total skor sikap terhadap kesehatan gigi tertinggi adalah 52 dan terendah 13 dibagi menjadi 3 kategori yaitu: kurang $13-25$, cukup 26 - 39, dan baik $40-52$. Alat ukur kebiasaan menginang, terdiri dari 6 aitem pernyataan pilihan ganda dibuat oleh peneliti sendiri. Pernyataan benar diberi nilai 1 dan jawaban yang salah diberi nilai 0 , sehingga skor tertinggi 6 dan skor terendah 0 , semakin tinggi nilai yang diperoleh semakin buruk kebiasaan menginang. Penyajian variabel ini dilaksanakan dengan membagi skor yang diperoleh menjadi 3 kategori berdasarkan Penilaian Acuan Patokan (PAP), kebiasaan menginang baik $0-1$, kebiasaan menginang sedang $2-4$, kebiasaan menginang buruk 5-6. dan alat ukur perilaku pemeliharaan kebersihan gigi dan mulut ibu hamil, kuesioner dibuat dengan menggunakan skala Likert. Nilai yang diperoleh dibuat kategori berdasarkan Penilaian Acuan Patokan (PAP) dengan menggunakan nilai tertinggi dan terendah. Total skor perilaku pemeliharaan kebersihan gigi dan mulut tertinggi adalah 44 dan terendah 11 , dibagi menjadi 3 kategori yaitu : kurang 11-22, cukup 23-34, dan baik 35-44.

Uji validitas dilakukan pada 30 orang ibu hamil, koefisien korelasi masing-masing aitem adalah $\geq 0,30$, sedangkan uji reliabilitas dengan memperoleh alpha $>0,60$. Data penelitian dianalisis dengan menggunakan análisis korelasi product moment dan regresi berganda. ${ }^{12}$

\section{HASIL PENELITIAN}

Responden pada penelitian ini berjumlah 97 ibu hamil yang berkunjung di Poli KIA dan Posyandu di Puskesmas Baumata Kabupaten Kupang. Responden berumur 26-30 tahun sebesar $39,2 \%$, dilihat dari umur kehamilan $>6$ bulan sebesar $47,4 \%$, dilihat dari kehamilannya, mayoritas responden kehamilan anak yang kedua sebesar $(37,1 \%)$.

Distribusi responden berdasarkan perilaku pemeliharaan kebersihan gigi dan Mulut ibu hamil disajikan pada Tabel 1

Tabel 1. Distribusi Perilaku Pemeliharaan Kebersihan Gigi dan Mulut Ibu Hamil $(n=97)$

\begin{tabular}{llccc}
\hline \multirow{2}{*}{ No. } & Kategori Skor & Rentang Skor & \multicolumn{2}{c}{ Frekuensi } \\
\cline { 3 - 5 } & & $\mathbf{n}$ & $\%$ \\
\hline 1. & Baik & $34-44$ & 28 & 28,9 \\
2. $\quad$ Cukup & $23-33$ & 69 & 71,1 \\
3. Kurang & $11-22$ & 0 & 0,0 \\
\hline Jumlah & & 97 & 100,0 \\
\hline
\end{tabular}


Applonia, dkk: Faktor-Faktor yang Mempengaruhi ...

Tabel 2. Distribusi Responden Berdasarkan Variabel Pengetahuan dan Perilaku Pemeliharaan Kebersihan Gigi dan Mulut ( $n=97)$

\begin{tabular}{|c|c|c|c|c|c|c|c|c|}
\hline \multirow{3}{*}{$\begin{array}{c}\text { Perilaku Pemeliharaan } \\
\text { kebersihan gigi dan mulut }(\mathrm{Y})\end{array}$} & \multicolumn{6}{|c|}{ Pengetahuan } & \multicolumn{2}{|c|}{ Total } \\
\hline & \multicolumn{2}{|c|}{$\begin{array}{c}\text { Kurang } \\
(0-2)\end{array}$} & \multicolumn{2}{|c|}{$\begin{array}{c}\text { Cukup } \\
(3-6)\end{array}$} & \multicolumn{2}{|c|}{$\begin{array}{l}\text { Baik } \\
(7-9)\end{array}$} & \multirow[b]{2}{*}{$\mathbf{n}$} & \multirow[b]{2}{*}{$\%$} \\
\hline & $\mathbf{n}$ & $\%$ & $\mathbf{n}$ & $\%$ & $\mathbf{n}$ & $\%$ & & \\
\hline Kurang (11-21) & 0 & 0,0 & 0 & 0,0 & 0 & 0,0 & 0 & 0,0 \\
\hline Cukup (22-33) & 0 & 0,0 & 44 & 45,4 & 25 & 25,8 & 69 & 71,1 \\
\hline Baik (34-44) & 0 & 0,0 & 6 & 6,2 & 22 & 22,7 & 28 & 28,9 \\
\hline Total & 0 & 0,0 & 50 & 51,5 & 47 & 48,5 & 97 & 100,0 \\
\hline
\end{tabular}

Tabel 3. Distribusi Responden Berdasarkan Variabel Sikap dan Perilaku Pemeliharaan Kebersihan Gigi dan Mulut ( $n=97$ )

\begin{tabular}{|c|c|c|c|c|c|c|c|c|}
\hline \multirow{3}{*}{$\begin{array}{c}\text { Perilaku Pemeliharaan } \\
\text { kebersihan gigi dan mulut }(\mathrm{Y})\end{array}$} & \multicolumn{6}{|c|}{ Sikap } & \multirow{2}{*}{\multicolumn{2}{|c|}{ Total }} \\
\hline & \multicolumn{2}{|c|}{$\begin{array}{c}\text { Kurang } \\
(13-25)\end{array}$} & \multicolumn{2}{|c|}{$\begin{array}{l}\text { Sedang } \\
(26-39)\end{array}$} & \multicolumn{2}{|c|}{$\begin{array}{c}\text { Baik } \\
(40-52)\end{array}$} & & \\
\hline & $\mathrm{n}$ & $\%$ & $\mathrm{n}$ & $\%$ & $\mathrm{n}$ & $\%$ & $\mathbf{n}$ & $\%$ \\
\hline Kurang (11-21) & 0 & 0,0 & 0 & 0,0 & 0 & 0,0 & 0 & 0,0 \\
\hline Cukup (22-33) & 1 & 1,0 & 58 & 59,8 & 10 & 10,3 & 69 & 71,1 \\
\hline Baik (34-44) & 0 & 0,0 & 18 & 18,6 & 10 & 10,3 & 28 & 28,9 \\
\hline Tootal & 1 & 1,0 & 76 & 78,4 & 20 & 20,6 & 97 & 100,0 \\
\hline
\end{tabular}

Tabel 4. Distribusi Responden Berdasarkan Variabel Kebiasaan Menginang dan Perilaku Pemeliharaan Kebersihan Gigi dan Mulut $(n=97)$

\begin{tabular}{|c|c|c|c|c|c|c|c|c|}
\hline \multirow{3}{*}{$\begin{array}{l}\text { Perilaku Pemeliharaan kebersihan gigi } \\
\text { dan mulut }(Y)\end{array}$} & \multicolumn{6}{|c|}{ Kebiasaan Menginang } & \multirow{2}{*}{\multicolumn{2}{|c|}{ Total }} \\
\hline & \multicolumn{2}{|c|}{$\begin{array}{c}\text { Buruk } \\
(5-6)\end{array}$} & \multicolumn{2}{|c|}{$\begin{array}{c}\text { Sedang } \\
(2-4)\end{array}$} & \multicolumn{2}{|c|}{$\begin{array}{l}\text { Baik } \\
(0-1)\end{array}$} & & \\
\hline & $\mathbf{n}$ & $\%$ & $\mathbf{n}$ & $\%$ & $\mathbf{n}$ & $\%$ & $\mathbf{n}$ & $\%$ \\
\hline Kurang (11-21) & 0 & 0,0 & 0 & 0,0 & 0 & 0,0 & 0 & 0,0 \\
\hline Cukup (22-33) & 30 & 30,9 & 38 & 39,2 & 1 & 1,0 & 69 & 71,1 \\
\hline Baik (34-44) & 2 & 2,1 & 22 & 22,7 & 4 & 4,1 & 28 & 228,9 \\
\hline Total & 32 & 33,0 & 60 & 61,9 & 5 & 5,2 & 97 & 100,0 \\
\hline
\end{tabular}

Tabel 1. menunjukkan bahwa $71,1 \%$ responden memiliki perilaku pemeliharaan kebersihan gigi dan mulut pada kategori cukup dan $28,9 \%$ diantaranya memiliki perilaku baik terhadap pemeliharaan kebersihan gigi dan mulut ibu hamil. Distribusi responden berdasarkan pengetahuan dan perilaku pemeliharaan kebersihan gigi dan mulut disajikan dalam tabulasi silang berikut ini:

Table 2. menunjukkan pengetahuan tentang pemeliharaan kebersihan gigi dan mulut sebesar $51,5 \%$ dan yang memiliki pengetahuan baik serta perilaku baik terhadap pemeliharaan kebersihan gigi dan mulut $22,7 \%$.
Tabel 3. menunjukkan bahwa $78,4 \%$ responden memiliki sikap terhadap kesehatan gigi pada kategori sedang dan $10,3 \%$ responden diantaranya memiliki sikap baik dan perilaku baik terhadap pemeliharaan kebersihan gigi dan mulut. Tidak ada responden yang digolongkan dalam kategori kurang.

Tabel 4. menunjukkan bahwa 61,9\% responden memiliki kebiasaan menginang pada kategori sedang dan $4,1 \%$ responden diantaranya memiliki kebiasaan menginang baik dan perilaku baik terhadap pemeliharaan kebersihan gigi dan mulut ibu hamil. 
Tabel 5. Hasil Analisis Korelasi antara Variabel Bebas dan Variabel Terikat (Perilaku Pemeliharaan Kebersihan Gigi dan Mulut Ibu Hamil)

\begin{tabular}{llcc}
\hline No & Variabel Bebas & Koefisien Korelasi $\left(r_{\text {xy }}\right)$ & $p$-Value \\
\hline 1. & Pengetahuan & 0,522 & 0,000 \\
2. & Sikap & 0,348 & 0,000 \\
3. & Kebiasaan menginang & $-0,441$ & 0,000 \\
\hline
\end{tabular}

Tabel 6. Hasil Analisis Regresi Berganda variabel bebas pengetahuan,sikap dan kebiasaan menginang

\begin{tabular}{lllll}
\hline Variabel Bebas & Koefisien Beta & $\begin{array}{l}\text { Standardized } \\
\text { Coefficients } \\
\text { Beta }\end{array}$ & $\mathbf{t}_{\text {hitung }}$ & $\begin{array}{l}\text { sig. } \\
(\boldsymbol{p} \text {-Value })\end{array}$ \\
\hline Konstanta & 21,032 & -- & -- & -- \\
Pengetahuan & 0,831 & 0,389 & 4,557 & $\left.0,000^{*}\right)$ \\
Sikap & 0,211 & 0,266 & 3,322 & $\left.0,001^{*}\right)$ \\
Kebiasaan menginang & $-0,651$ & $-0,272$ & $-3,199$ & $\left.0,001^{*}\right)$ \\
\hline$R$ & & $=0,645$ & \\
$R^{2}$ & & $=0,416$ & \\
$F_{\text {hitung }}$ & $=22,052$ & & \\
Sig. $(p$-Value $)$ & & $\left.=0,000^{*}\right)$ & & \\
\hline
\end{tabular}

Tabel 7. Sumbangan Efektif Variabel Bebas terhadap Perilaku Pemeliharaan Kebersihan Gigi dan Mulut Ibu Hamil

\begin{tabular}{llccc}
\hline \multirow{2}{*}{ No } & \multirow{2}{*}{ Variabel Bebas } & \multicolumn{2}{c}{$\mathbf{9 5 \%}$ Confidence Interval } & \multirow{2}{*}{ Partial Eta Squared } \\
\cline { 3 - 4 } & & Lower Bound & Upper Bound & \\
\hline 1. & Pengetahuan & 0,469 & 1,193 & 0,183 \\
2. & Sikap & 0,085 & 0,338 & 0,106 \\
3. & Kebiasaan menginang & -1.055 & $-0,247$ & $-0,099$ \\
\hline
\end{tabular}

Hasil analisis korelasi menunjukkan bahwa variabel pengetahuan, sikap ada hubungan positif dan signifikan sedangkan kebiasaan menginang berpengaruh negatif yang signifikan $(p<0,05)$ disajikan pada tabel 5 .

Pada analisis regresi berganda, semua variabel bebas pengetahuan, sikap, kebiasaan menginang mempunyai pengaruh signifikan terhadap perilaku pemeliharaan kebersihan gigi dan mulut ibu hamil. Hasil analisis disajikan pada Tabel 6.

Hasil analisis regresi berganda diperoleh koefisien determinasi $\left(R^{2}\right)$ sebesar 0,416 , hal ini menunjukkan secara statistik variabel pengetahuan, sikap dan kebiasaan menginang mampu memprediksikan perilaku pemeliharaan kebersihan gigi dan mulut ibu hamil (Y) di Puskesmas Baumata
Kabupaten Kupang sebesar $41,6 \%$ dan selebihnya $58,4 \%$ ditentukan oleh variabel di luar penelitian ini.

Hasil analisis Partial Eta Squared menunjukkan bahwa variabel pengetahuan tentang pemeliharaan kebersihan gigi dan mulut $\left(\mathrm{X}_{1}\right)$ merupakan variabel yang paling dominan memberikan kontribusi efektif terhadap perilaku pemeliharaan kebersihan gigi dan mulut ibu hamil, memberikan sumbangan sebesar $18,3 \%$. Distribusi hasil analisis partial eta squared disajikan pada Tabel 7 .

\section{PEMBAHASAN}

Hasil penelitian menunjukkan bahwa $71,1 \%$ responden memiliki perilaku pemeliharaan kebersihan gigi dan mulut dengan kategori cukup dan selebihnya $28,9 \%$ responden kategori baik, 
sehingga dapat disimpulkan bahwa perilaku responden cenderung kategori baik. Hubungan perilaku dengan pengetahuan, kepercayaan dan persepsi yang dijelaskan dalam Health Belief Model bahwa kepercayaan seseorang terhadap rentanan dirinya dari suatu penyakit dan potensi penyakit, akan menjadi dasar seseorang melakukan tindakan pencegahan terhadap penyakit tersebut. ${ }^{13}$

Salah satu faktor yang berpengaruh terhadap masalah kesehatan gigi dan mulut pada masa kehamilan adalah faktor perilaku. Oleh karena itu, pemeliharaan kebersihan gigi dan mulut pada masa kehamilan perlu diperhatikan. ${ }^{6,14}$

Hasil analisis multivariat variabel pengetahuan berpengaruh secara signifikan $(p=0,000)$ terhadap perilaku pemeliharaan kebersihan gigi dan mulut ibu hamil. Hasil penelitian menunjukkan rerata nilai pengetahuan 6,44 berada pada kategori cukup cenderung kearah baik. Hasil penelitian Al-Attas ${ }^{16}$ menunjukkan bahwa ada hubungan yang signifikan 'pengetahuan ibu hamil dengan pemeliharaan kesehatan gigi dan mulut selama masa kehamilan.

Hasil analisis multivariat variabel sikap terhadap kesehatan gigi berpengaruh secara signifikan $p=0,001$ terhadap perilaku pemeliharaan kebersihan gigi dan mulut ibu hamil. Hasil penelitian menunjukkan rerata nilai sikap 35,62 berada pada kategori cukup. Tidak ada responden dengan sikap terhadap kesehatan gigi dengan kategori kurang.

Penelitian Hamissi, $\quad \mathrm{dkk}^{16}{ }^{16}$ menunjukkan adanya pengaruh signifikan antara sikap dengan kunjungan ibu hamil ke dokter gigi. Namun, AlAttas ${ }^{15}$ dalam penelitiannya mendapatkan sikap negatif terhadap kunjungan ibu hamil ke dokter gigi selama masa kehamilan, hanya sebagian yang mengunjungi dokter gigi ketika sakit dan menganggap kunjungan tidak perlu terutama ibu hamil dengan latar belakang pendidikan rendah, jumlah kehamilan dan jumlah anak.

Hasil analisis multivariat variabel kebiasaan menginang berpengaruh negatif yang signifikan $\mathrm{p}=0,002$ terhadap perilaku pemeliharaan kebersihan gigi dan mulut ibu hamil, sehingga semakin sering menginang semakin buruk perilaku pemeliharaan kebersihan gigi dan mulut. Secara deskriptif menunjukkan bahwa $61,9 \%$ responden memiliki kebiasaan menginang pada kategori sedang dan $33,0 \%$ responden memiliki perilaku buruk kebiasaan menginang sedangkan nilai rerata skor menginang 3,75 berada pada kategori sedang, sehingga dapat disimpulkan bahwa 94,9\% responden masih menginang.

Kebiasaan menginang tidak berbeda dengan kenikmatan lain seperti tembakau, merokok, teh dan kopi, sehingga penginang yang sudah kecanduan sukar untuk menghilangkannya. Menginang dapat menghambat proses karies gigi, disamping itu sirih menjaga kesehatan mulut, daun sirih mempunyai aktifitas antioksidan. ${ }^{9}$ Efek negatif menginang dapat menyebabkan pewarnaan gigi dan kerusakan jaringan periodontal. ${ }^{10}$

\section{KESIMPULAN}

Berdasarkan hasil penelitian maka dapat disimpulkan sebagai berikut: 1.Pengetahuan dan sikap terhadap kesehatan gigi berpengaruh secara signifikan terhadap perilaku pemeliharaan kebersihan gigi dan mulut ibu hamil sebesar $41,6 \%$ dan selebihnya $58,4 \%$ ditentukan oleh variabel di luar penelitian ini. 2. Kebiasaan menginang berkorelasi negatif secara signifikan terhadap perilaku pemeliharaan kebersihan gigi dan mulut ibu hamil.

\section{DAFTAR PUSTAKA}

1. Hartati, Rusmini, Waluyo. Analisis Faktor Faktor yang Berhubungan dengan Kejadian Gingivitis pada Ibu Hamil di Wilayah Kerja Puskesmas Talang Tegal. Jurnal IImiah Keperawatan. 2011; 7 (3): 170 - 189.

2. Depkes RI. Model Penyalahgunaan Dokter Gigi dan Perawat Gigi di Sekolah. Jakarta: Depkes Rl; 2003.

3. Depkes RI. Riset Kesehatan Dasar, Badan Penelitian Dan Pengembangan Kesehatan. Jakarta: Depkes Rl; 2008.

4. Alwaeli HA, Al-Jundi SH. Periodontal Disease Awareness Among Pregnant Women and Its Relationship With socio-Demographic 
Variables. International $\mathrm{J}$ of Dent Hygiene. 2005; $3: 74-82$.

4. Honkala S, Al-Ansari J. Self-Reported Oral Health, Oral Hygiene Habits, And Dental Attendance of Pregnant Women in Kuwait. J of Clinical Periodontology. 2005; 32 : 809 814.

5. Ekaputri N, Loes FD, Sjahruddin. Hubungan Perilaku Wanita Hamil dalam Membersihkan Gigi dan Mulut dengan Kedalaman Poket Periodontal selama Masa Kehamilan. Majalah IImiah Kedokteran Gigi. 2005; 62 - 90.

6. Dinkes Propinsi NTT. Profil Kesehatan Propinsi Nusa Tenggara Timur. Edisi Perdana. Kupang: Dinkes Prop NTT; 2011.

7. Dinkes Kabupaten Kupang. Dinas Kesehatan Kabupaten Kupang. Kupang: Dinkes Kab; 2009

8. Susiarti S. Jenis - Jenis Pengganti Pinang Dan Gambir Dalam Budaya Menginang Masyarakat Di Kawasan Taman Nasional Wasur Mersuke, Papua. Biodiversitas. 2008; 6 (3): 217-219.
9. Trivedy CR, Craig G. Warnakulasuriya S. The Oral Health Consequences of Chewing Areca. Addiction Biology. 2002; 7: 115 - 125.

10. Sastroasmoro S, Ismail S. Dasar - Dasar Metodologi Penelitian Klinis. Edisi ke 4. Jakarta: Sagung Seto; 2011.

11. Aswar S. Sikap Manusia Teori Dan Pengukurannya Edisi 2. Yogyakarta: Pustaka Pelajar; 2011.

12. Budiharto. Pengantar Ilmu perilaku Kesehatan dan Pendidikan Kesehatan Gigi. Jakarta: EGC; 2010.

13. Hasibuan S. Perawatan Dan pemeliharaan Kesehatan Gigi Dan Mulut Pada Masa Kehamilan. USU Digital Library. Bagian IImu Penyakit Mulut Fakultas kedokteran Gigi Universitas Sumatra Utara. 2004; 1 - 6.

14. Al Attas SA. Jeddah Adults Oral Health Knowledge, Attitude and Behavior. Egyptian Dental J. 2004; 50 (3): 1357 - 1367.

15. Hamissi J, Vaziri PB, Davaloo A. Evaluating Oral Hygiene Knowledge and Attitude of Pregnant Women. Iranian J Publ Health. 2010; 39 (1): $28-31$. 